\title{
The intersection of culture in the provision of dementia care: A systematic review I
}

\author{
Joanne Brooke, Camille Cronin, Marlon Stiell, Omorogieva Ojo
}

\begin{abstract}
Aim: To understand the intersection of healthcare professionals' and care workers' culture and their provision of person-centred care for people with dementia.
\end{abstract}

Background: Due to the nature of global immigration and recruitment strategies, healthcare is provided by a culturally diverse workforce. Consequently, there is a need to understand healthcare professionals' and care workers' cultural values of illness, disease and dementia. Cultural values and beliefs regarding dementia and care of the older person differ, and currently there is a lack of clarity regarding the intersection of culture in the provision of person-centred dementia care.

Method: A search of the following databases was completed: Medline, CINAHL, Psychology and Behavioural Sciences, PsycINFO and PubMed for papers published from $1^{\text {st }}$ January 2006 to $31^{\text {st }}$ July 2016.

Results: A total of seven qualitative studies met the inclusion and exclusion criteria, all explored the impact of healthcare professionals' and care workers' culture in relation to their provision of person-centred dementia care. A meta-synthesis of the data from these studies identified four themes: cultural perceptions of dementia, illness and older people, impact of cultural perceptions on service use, acculturation of the workforce, and cross cultural communication.

Conclusion: Limited evidence was found on the impact of healthcare professionals' and care workers' culture on their provision of person-centred dementia care. The intersection of culture and dementia included the understanding of dementia, care and family roles. Acculturation of migrant healthcare workers to the culture of the host country, workplace, and support with the communication was identified as necessary for the provision of person-centred dementia care.

Relevance to clinical practice: Open access education and training to support communication is required, alongside the development of robust interventions to support the process of acculturation of migrant healthcare professionals and care workers to provide culturally competent person-centred dementia care.

Keywords: dementia, healthcare workforce, culture, person-centred care 


\section{What does this paper contribute to the wider global clinical community?}

- An understanding of how healthcare professionals' and care workers' culture intersects with their understanding and provision of person-centred dementia care.

- Education, training and support are required by migrant healthcare professionals and care workers to enable acculturation and to enhance their communication with patients and colleagues.

\section{INTRODUCTION}

Worldwide 46.8 million people were estimated to be living with dementia in 2015 , and this is expected to double every 20 years rising to over 131 million by 2050 (Alzheimer's disease International (ADI) 2015). A new diagnosis of dementia occurs every 3 seconds, with 9.9 million new cases reported in 2015 (Prince et al. 2014). In the UK, 850,000 people are living with dementia; the majority 774,000 are over the age of 65 years, with a financial cost of over $£ 26$ billion per annum (Prince et al. 2014; Alzheimer's UK 2015).

Dementia is an umbrella term for a collective set of progressive medical syndromes affecting memory, thinking, behaviour and emotions (Department of Health 2009) and "does not differentiate between social, economics, ethnic or geographical boundaries" (ADI 2015). Caring for someone with dementia requires a specific set of skills, knowledge, understanding and the ability to respond to a complex range of physical, behavioural, and psychological symptoms (Kimzey et al. 2016; Flaskerud 2009, Gheno et al. 2012).

Recent advances in treatment, care, interventions and support for people with dementia have focused on the development of pharmacological and non-pharmacological interventions (Cooper et al. 2013; Livingston et al. 2014; Reijnders et al. 2013). The development of non-pharmacological interventions has in part evolved through personcentred care, which originated from the work of Tom Kitwood (1997).

Person-centred care is based on the concept of personhood, "a socially created entity established through the action of others" (Douglass et al. 2010, p.568). Person-centred care is the maintenance of an individual's personhood, through the context of personal and social relationships (Kitwood 1997). Four elements of person-centred care have been identified: valuing people with dementia and those who care for them; treating people as individuals; viewing the world from the perspective of the person with dementia, and providing a positive social environment for the person with dementia (Brooker 2004). Viewing the world from the perspective of the person with dementia includes an understanding of their culture. 
Many definitions of culture exist, however culture impacts on: biological processes, behaviour and interpretations of behaviour, and social groups. The impact of culture is different from universal human behaviour and unique individual personality (Spencer-Oatey 2012). Matsumoto (1996) defined culture as a group of people who have shared attitudes, values and beliefs, which are indirectly communicated from one generation to the next, and interpreted at an individual level.

Cultural groups are not homogenous; it is the common traditions, symbols and beliefs that give rise to a shared identity (United Nations Educational, Scientific and Cultural Organisation (UNESCO) 2009). An important element of culture is the dynamic nature of a shared identity, which is influenced by immigration and from generation to generation. Both these factors challenge identities associated with culture (UNESCO 2009).

Culturally significant activities are embedded in everyday practices such as food preferences, preparation and fasting. These cultural activities become habit and need to be included or adopted in person-centred care (Hanssen \& Kuven 2016). For example, culturally relevant food was found to impact positively on mood, memory and wellbeing of people with dementia (Douglass et al. 2010).

A framework has been developed to support the provision of culturally appropriate personcentred care and defines three interrelated and intersectional domains: the subjective experience of dementia, an interactional environment and a socio-cultural context. These domains enable an understanding of the concept of and ability to support an individual's personhood (O'Connor et al. 2007). Socio-cultural factors need to encompass a broad conceptualisation of culture, which includes symbols, beliefs and customs that influence group and individual behaviour (Matsumoto 1996). An understanding of these elements is essential when supporting the personhood of an individual with dementia.

Globally, strategies to support the implementation of culturally appropriate care have been developed through an integrated and collaborated approach. One example is the Queensland Partners in Culturally Appropriate Care (PICAC) project, a partnership between ethnic community groups and residential aged care services (Goldman 2009). Research has also focused on the impact of family caregivers' culture, to understand care making decisions, medication use and accessing services (van Wezel et al. 2016; Gillespie et al. 2015; Xiao et al. 2013).

Conversely, the impact of a culturally diverse healthcare workforce in dementia care has not been comprehensively explored to date. This workforce includes both healthcare professionals, such as trained nurses, doctors and therapists, as well as care workers, who have received some form of training, but are not on a professional register. The workforce 
within the aged care sector in many countries now relies upon migrants from low-income countries who have experienced a degree of instability either politically, economically or both (Walsh \& Shutes 2013; Nichols et al. 2015).

Therefore, there is a need to understand the culturally diverse healthcare workforce. This is essential as there are cultural differences in the conceptualisation of dementia, for example some cultures view dementia as part of the normal aging process, whilst other cultures, view dementia as an embarrassment or dishonourable (Dilworth-Anderson \& Gibson 2002).

Many cultures believe their own cultural group experience lower prevalence rates of dementia than other cultural groups (Komaric et al. 2012). This is perhaps reflected in some languages where only one word is used to describe a range of mental health disorders including dementia. This results in a less accurate and later diagnosis, with individuals seen in the same context as those experiencing schizophrenia or depression (Mendes 2015).

Applying Matsumoto's (1996) definition of culture, how do people from one culture understand the dynamic attitudes, values, beliefs and behaviours of other cultures to provide person-centred care (Dilworth-Anderson \& Gibson 2002)? In many countries including the UK, there is a culturally diverse dementia workforce providing person-centred care to a culturally diverse population of people living with dementia.

To date there are no systematic reviews of the literature to support an understanding of the impact of healthcare professionals' and care workers' culture on their provision of personcentred dementia care. Literature has focused on the need for nurses to be culturally competent when providing person-centred care (Singleton \& Krause 2009), but has not addressed how nurses own culture intersects with their provision of care to support the personhood of a person with dementia. This is an important aspect that may influence the provision of care to one of the most vulnerable patient groups.

\section{AIM}

To understand the intersection of healthcare professionals' and care workers' culture and their provision of person-centred care for people with dementia.

\section{METHOD}

A comprehensive search of published literature was completed with adherence to systematic review guidelines (Bettany-Saltikov 2012; Wright et al. 2007). Databases searched included: EBSCO host, which encompassed Medline, Psychology and Behavioural Sciences, PsycINFO and Cumulative Index to Nursing and Allied Health Literature (CINAHL) and PubMed. Search terms included recognised Medical Subject Headings (MeSH) and specific 
subject headings, searches made were: 'culture' and 'workforce' and 'dementia'; and 'culture' and 'carers' and 'dementia'; 'culture' and 'migrant worker' and 'dementia'; 'culture' and 'healthcare professional' and 'dementia'. The review process included a search of reference lists of identified articles and grey literature such as: government, local council and charity initiatives with active dementia programmes.

The inclusion criteria included articles published in the English language between $1^{\text {st }}$ January 2006 and $1^{\text {st }}$ September 2016. Articles published prior to $1^{\text {st }}$ January 2006 were not included, because dementia was highlighted as a public health challenge by the World Health Organisation at this time. Simultaneously, in the UK prominent dementia guidelines were published with a focus on improving care and support for people with dementia and their families (National Institute for Health and Clinical Excellence guidelines: CG42 and Scottish Intercollegiate Guidelines: SIGN 86).

Further inclusion criteria included: primary data collection with a focus on understanding a culturally diverse workforce caring and supporting people with dementia and their families, across any health or social care setting. Studies were excluded if the focus of culture was to explore or develop person-centred care, or the culture of family members of people with dementia, rather than the exploration of the impact of healthcare workers' own culture on the provision of person-centred care.

Duplicate papers were removed, titles screened and papers read by the team. The decision to include or exclude papers was agreed by consensus of all authors and through consultation with J.B.

Due to the qualitative nature of studies included in the review a meta-synthesis was completed with an underling approach of thematic analysis (Hannes \& Lockwood 2011), which supported the analysis and synthesis of qualitative findings and the emergence of an expanded interpretation and understanding of the topic (Cooke et al. 2012).

Thematic analysis commenced with the extraction of data, concepts and important issues reported in each study by two authors (J.B and C.C). Analysis was completed by the same authors, who coded extracted data independently and then jointly, to identify themes in an iterative manner until no new themes emerged.

\section{Quality Appraisal}

Each paper was assessed against the Critical Appraisal Skills Programme (CASP) for qualitative studies, which considers the appropriateness of methodology, design, recruitment strategy, data collection, data analysis, findings, and the value of the research (CASP 2014). The only element highlighted across many of the papers $(n=5)$ was the lack of clear 
reporting and consideration of the relationship between the researcher and participants (Antelius \& Kiwi 2015; Boughtwood et al. 2011; Emilsson 2011; Nichols et al. 2015; Yong \& Manthorpe 2016).

\section{FINDINGS}

The results of the search are summarised in a PRISMA diagram (Moher et al. 2009), 606 citations were identified as being potentially relevant to the review (refer to Figure 1). Following the removal of 131 duplicates, a review of the title excluded a further 565 citations. Abstracts of the remaining citations were reviewed and a further 19 were excluded. Full text articles were then retrieved and reviewed, and a further 15 citations excluded. Only seven papers met the above inclusion and exclusion criteria.

\section{Study Characteristics}

Table 1 provides an overview of the characteristics of included studies. The review identified qualitative studies exploring experiences and opinions of culturally diverse health care professionals. The studies were completed in a number of countries which included: Australia (Boughtwood et al. 2011; Nichols et al. 2015; Xiao et al. 2015), Sweden (Antelius \& Kiwi 2015; Emilsson 2011), Norway (Egede-Nissen et al. 2016) and England (Young \& Manthorpe 2016). Several studies $(n=4)$ included both qualified nurses and care workers (Antelius \& Kiwi 2015; Boughtwood et al. 2015; Nichols et al. 2015; Young \& Manthorpe 2016), one study included care workers only (Xiao et al. 2015). Two studies included other healthcare professions, of which one study included qualified nurses, a care worker, and a physiotherapist (Egede-Nissen et al. 2016), and one study included doctors, therapists, dieticians, social workers, qualified nurses and care workers (Emilsson 2011). The majority of studies ( $n=6$ ) applied semi-structured interviews (Antelius \& Kiwi 2015; Boughtwood et al. 2011; Egede-Nissen et al. 2016; Emilsson 2011; Young \& Manthorpe 2016; Xiao et al. 2015), Xiao et al. (2015) also included a focus group; Nichols et al. (2015) included semistructured questionnaires and a workshop. All studies reported an underlying philosophy that guided their methodological approach, which ranged from ethnography (Antelius \& Kiwi 2015), modified framework analysis (Boughtwood et al. 2011), hermeneutic phenomenology (Egede-Nissen et al. 2016), content analysis (Emilsson 2011), interpretative phenomenology (Yong \& Manthorpe 2016) and Gadamer's hermeneutics (Xiao et al. 2015).

\section{Themes}

Four themes emerged from the thematic analysis of the meta-synthesis: cultural perceptions of dementia, illness and older people, impact of cultural perceptions on service use, acculturation of the workforce, and cross-cultural communication. 


\section{Cultural perceptions of dementia, illness and older people}

Cultural perceptions were reflected in the terminology used to define dementia as the use of the word dementia was only adopted by Iranian and Vietnamese care workers on migration to Western cultures (Antelius \& Kiwi 2015; Xiao et al. 2015). In Iran dementia described someone who lacked intelligence, was a lunatic, a fool or senile. The word senile was not related specifically to older people, but also inferred mental illness, and was used to describe soldiers with post-traumatic stress disorder (Antelius \& Kiwi 2015). Whilst in Vietnam, there is no word for dementia and the term translates as confusion (Xiao et al. 2015).

Cultural perceptions of dementia were reflected in care workers' interpretation of the behaviour of residents with dementia. Iranian staff did not view dementia as a disease or the cause of residents' behaviour. Residents were viewed as being very sick, experiencing 'day dreams', or as burdensome and troublesome people. Iranian staff discussed the accepted beliefs that older people will forget or even speak out loud to dead parents, as this is part of the process of passing over to the next world (Antelius \& Kiwi 2015).

Differences in cultural perceptions of old age rather than dementia also emerged, Emilison (2011) found staff working in care homes with residents with dementia in France, Portugal, and Sweden, viewed residents as requiring support due to their age and not due to their dementia. In France staff viewed the residents as 'old and ill', in Portugal as 'old and in need of help', and in Sweden as 'old' and not in relation to their cognitive abilities. Vietnamese care workers in Australia believed dementia was part of the normal ageing process, relating the onset to bereavement and depression (Xiao et al. 2015). Dementia as a normal part of ageing was also the view of care workers from: south-east Asia, China, Africa, Philippines and Europe (Nichols et al. 2015).

\section{Impact of cultural perceptions on service use}

Cultural perspectives were found to strongly influence health seeking behaviours and the use of supportive health and social care services. Iranian and Vietnamese care workers and Spanish and Italian link workers discussed the stigma and shame of placing a family member in a care home (Antelius \& Kiwi 2015; Xiao et al. 2015; Boughtwood et al. 2011). The emphasis within these cultures and workers from Asia, China, African and the Philippines working in care homes in Australia was filial piety and the family's role in caring for older family members at home (Nichols et al. 2015).

A Spanish participant described cultural pressure, as a strong covert pressure to care for older family members. Therefore, if the need arose to place a family member in a residential setting this would bring shame and embarrassment and was a poignant reason for keeping a 
diagnosis of dementia secret (Boughtwood et al. 2011). This was compounded by the belief of Iranian care workers that older family members living in Iran would not develop dementia, leading to further secrecy and hiding of family members with dementia (Antelius \& Kiwi 2015).

However, the influence of the new culture on migrant Vietnamese family caregivers supported a change from hiding a family members' diagnosis of dementia to being open and accessing and accepting health and social care support (Xiao et al. 2015). For these migrant family caregivers' acculturation to the Australian culture supported their health seeking behaviours, especially when services were aimed for and delivered by Vietnamese people. From this perspective respite care and short-term residential care options were positive alternatives to placing a relative in a permanent residential setting (Xiao et al. 2015).

\section{Acculturation of the workforce}

Acculturation of migrant care workers was found to occur over a period of time and through five main themes (Young and Manthorpe 2016). The first stage of acculturation was associated with an initial cultural shock as care workers reported anxiety and a sense of insecurity due to a lack of awareness of workplace culture including; behaviours, social interactions, and work policies. Migrant care workers realised they needed to understand the culture of the workplace, as well as the culture of the country they had emigrated to (Nichols et al. 2015; Young and Manthrope 2016).

Culturally and Linguistically Diverse (CaLD) care workers who had migrated to Australia felt they needed support to understand the Australian culture. There were simple but important concepts not understood by CaLD care workers, such as food products including marmalade or vegemite, which impacted on the care they provided (Nichols et al. 2015). During this phase of acculturation, care workers acknowledged that communication with work colleagues and residents was problematic (Young \& Manthrope 2016).

An understanding of the English language, culture, and workplace supported migrant care workers to re-evaluate their new role. Workplace acculturation occurred as care workers began to feel a sense of accomplishment in their work, with improved knowledge of dementia that positively supported the care they provided (Young \& Manthorpe 2016).

The process of acculturation was hindered by cultural barriers as some care workers experienced prejudice and stereotyping from residents and work colleagues (Nichols et al. 2015; Egede-Nissen et al. 2016). Some residents openly expressed they would preferred not to be cared for by someone from a different culture (Nichols et al. 2015). Despite some negative experiences and discrimination, migrant care workers reported enjoying their work 
and finding their new caring role as rewarding, as they were paid to care for residents, which supported their cultural beliefs of caring for older people (Emilison 2011; Egede-Nissen et al. 2016).

Finally, some migrant care workers expressed hope, which was associated with the hope of leaving the care home environment and training to become a qualified nurse (Young \& Manthorpe 2016).

\section{Cross-cultural communication}

Cross-cultural communication was an important and recurrent theme (Egede-Nissen et al. 2016; Nichols et al. 2015). Everyday verbal and non-verbal communication, use of body language and facial expressions were all recognised as important by carers from Brazil, Philippines, Monte Negro and Serbia and applied when communicating with patients living with dementia. These care workers recognised the value of using appropriate language to avoid misunderstandings, but felt they were culturally unaware of how to do this. Care workers reported incorrect pronunciation or use of a word might result in a patient becoming agitated, and this would be perceived as their responsibility despite striving to understand their patients (Egede-Nissen et al. 2016).

Nichols et al. (2015) found cross-cultural communication challenges not only existed between care workers and patients with dementia, but extended to communications with other members of staff. Both CaLD and non-CaLD care workers reported concerns regarding language comprehension when discussing the care and needs of residents. Examples of concern included the use of slang terms and colloquial language that was applied through cultural norms and interpersonal communication (Nichols et al. 2015).

The need for English language lessons was highlighted. In some care environments these were available, however migrant care workers were not aware of them or how to access them (Nichols et al. 2015; Egede-Nissen et al. 2016).

\section{DISCUSSION}

The themes identified from this review provide support for the existence of differences in cultural perceptions of: dementia, illness and older people among migrant care workers, and attitudes and beliefs regarding the use of dementia services. Cultural differences created challenges with communication when caring for people with dementia and when reporting to work colleagues. The process of acculturation of migrant care workers was identified, with an emphasis on the need to understand the culture of their new country and those whom they care for, as well as the culture of their workplace. 
The cultural background of migrant care workers provides an understanding of how the meaning of dementia influences the: interpretation of dementia, behaviour of people with dementia and their provision of person centred care (Hanssen 2013). These differences emerged from and were defined by cultural norms, values, traditions, beliefs, and often developed through the integration of the individual's experiences, thoughts and actions (Hanssen 2013).

The dynamic nature of culture and understanding of dementia has been explored through anthropological studies in India. Cohen (1998) and McCabe (2006) reported the experience of dementia in India was constructed through specific cultural discourses, until the introduction of a Western medical approach with diagnosing Alzheimer's disease. The interpretation of behaviour in old-age was then through the lens of a biological model rather than original cultural scripts. Unfortunately, none of the studies in this review included care workers from India, so the impact of a Western approach to dementia on this migrant workforce is yet unknown.

Care workers from CaLD backgrounds understood dementia as a natural process of ageing, and cared for older people in residential settings as they were ill and in need of help, and did not relate this to dementia or cognitive impairment (Nichols et al. 2015; Emilison 2011). However, care workers also expressed their beliefs that speaking aloud to dead parents by older people was a natural part of ageing (Antelius \& Kiwi 2005). These beliefs need to be challenged to support an early and accurate diagnosis of dementia, and treatment and provision of appropriate support and care. For example, the implementation of interventions such as SHARE (Support, Health, Activities, Resources, and Education) is required. SHARE is a programme used in the early stages of dementia to plan for future care with family members, enabling decision making in the later stages of dementia to be inclusive and respectful of the person's wishes (Orsulic-Jeras et al. 2016).

Previous studies have reported CaLD workers' cared for older family members at home due to their cultural beliefs, and a lack of understanding of dementia as a healthcare issue and dementia residential services (Brodaty \& Donkin 2009; Shanley et al. 2012). These studies support an important aspect highlighted in the current review: the need to provide education and training for migrant care workers, to support their understanding of dementia, early diagnosis, intervention and treatment, and the possibility that some people with dementia may require long-term residential care. 
The stigma associated with placing an older family member in residential care emerged throughout the studies included in this review, with an emphasis on filial piety across several cultures. Stigma was associated with heightened stress, shame, and impacted negatively on family relationships (Antelius \& Kiwi 2015; Kanwar \& Whomsley 2011).

In Pakistan, the concept of 'family' forms the basis for social structure and identity, alongside the belief it is an honour for younger members to look after older members of the family at home. However, homecare from external agencies was usually accepted (Kanwar \& Whomsley 2011). The provision of respite care, rather than long-term residential care also emerged from the current review as an acceptable form of support (Xiao et al. 2015).

Care workers need to be aware of the culture of those they care for and their families, as cultural beliefs and filial piety can impact negatively on family care givers' financial security, lifestyles, friendships and health (Greaves 2013). The responsibility and duty to care for older family members due to filial piety may also increase caregiver burden (Yan \& Kwok 2010). Other factors that impact on caregiver burden include co-residing, a lack of domestic help and care support, which have been associated with increased caregiver verbal abuse (Yan \& Kwok 2010).

Migrant care workers need to understand filial piety as for some cultures this is an important virtue and a primary duty of respect and obedience to care for one's parents or older family members, and is a key determinant of moral value of a person in their society. The cultural significance of filial piety is important in some Asian communities (Kanwar \& Whomsley 2011) and in migrant care workers (Antelius \& Kiwi 2015). However, migrant care workers also need to be aware of the changing beliefs of filial piety in family caregivers who have migrated to Western cultures, and to be able to appropriately support their decision making (Yan \& Kwok 2010; Yuan \& Wang 2011).

\section{Acculturation of the workforce}

Acculturation was defined in 1936 by Redfield et al. (p.136) as "change that occurs when individuals from different cultural backgrounds come into prolonged, continuous, first-hand contact with each other". The process of acculturation occurs at both an individual level, with the adaptation of values, beliefs and identities and at a group level, with adaptation of social and cultural systems (Berry 2003).

Several frameworks have been developed to provide an understanding of the acculturation process for migrant workers (Adrends-Toth \& van de Vijver 2006; Ho \& Chiang 2015). Adrens \& van de Vijver (2006) identified three elements: the impact of differences between the original culture and the new culture, the extent to which the new culture is adopted, 
whilst maintaining original cultural beliefs, and the outcome of acculturation, that can include well-being and social competence in both cultures. More recently a framework by Ho \& Chiang (2015) explored psychological and behavioural changes of adaptation, which were influenced negatively by environment stressors and positively by personal and psychological resources.

The first element of Adrends-Toth \& van de Vijver's (2006) framework, the impact of differences between the original culture and the new culture is highlighted by migrant care workers need to understand culturally appropriate food for their patients, such as marmalade, whilst simultaneously maintaining their own culturally driven food consumption (Young \& Manthorpe 2016). Ho \& Chiang's (2015) framework identified negative environment stressors as indicators of poor acculturation, in the current review prejudice and stereotyping from patients and work colleagues were highlighted, but were not related to acculturation (Nichols et al. 2015; Egede-Nissen et al. 2016).

However, the current review identified the need for migrant care workers to adapt to both their host countries culture and workplace culture. The acculturation of the dementia care workforce in care home settings included the development of more Westernised views of dementia and dementia care, which supported migrant carer workers to evaluate their new roles as rewarding (Egede-Nissen et al. 2016). Finally, migrant carer workers applied a personal and psychological resource when they expressed hope of developing a nursing career (Young \& Manthorpe 2016).

Leininger (1997) developed an assessment tool to understand the extent to which a group or individuals have become acculturated. Further tools have been developed, but the majority are single scale tools that measure one specific cultural group, measuring outcomes such as explicit behaviours rather than the processes involved (Celenk \& van de Vijver 2011). There is a need to develop validated and robust tools to understand the processes of acculturation of care workers in relation to the provision of culturally competent person-centred dementia care.

Acculturation of care workers has not been widely studied in relation to dementia care, although the importance of intercultural engagement at both an individual level and a group level had been identified (Berry et al. 2011). Kimzey et al. (2015) observed providing education and training on dementia, improved multi-cultural interactions at both individual and group levels, leading to a greater understanding of the needs of people with dementia, and supported care workers' acculturation and development of culturally competent personcentred care. 
Care workers require advanced communication skills to communicate with people with dementia, these include; verbal, body language and facial expressions, but also an understanding of slang terms and colloquial language (Egede-Nissen et al. 2016; Nichols et al. 2015). Communication skills are essential to build trust and partnership with people with dementia, their family members and work colleagues (Flaskerud 2009). However, an important element is understanding the cultural beliefs and values, and how these influence communication with patients with dementia and their colleagues (Nichols et al. 2015). Additionally, the use of medical jargon and different accents often result in lack of rapport between staff and patients/residents (Komaric et al. 2012).

Acculturation is vital in cross-cultural communication, linguistic acculturation of care workers has been studied widely, but not in relation to providing culturally appropriate person-centred dementia care. The importance of linguistic acculturation is to support socialisation into the workforce through understanding and using local accents and colloquial language (Zhou et al. 2011; Wheeler et al. 2013). The need to understand the meaning of words beyond a superficial level is required to build relationships with colleagues and patients (O'Neill 2011).

\section{Intersection of culture and dementia care}

The intersection of culture and provision of dementia care is important, as culture influences the understanding of dementia and care provided. Successful acculturation is essential to enable migrant care workers to provide culturally appropriate person-centred dementia care, understanding care workers' culture is equally important and needs to be considered when developing care provisions for people living with dementia.

\section{Limitations}

The review only included papers published in the English language and explored the impact of culture of the healthcare workforce in relation to the provision of person-centred dementia care. Studies reviewed were relatively small due to their qualitative nature, which suggests an area that lacks robust quantitative research.

\section{CONCLUSION AND RECOMMENDATIONS}

There remains the need for all care workers to understand dementia from a biopsychosocial perspective. An important element is that dementia is not a normal part of aging, but is caused by a number of biological diseases that impact on a person's memory, behaviour and emotions. Part of this approach is the need for the culturally diverse healthcare workforce to understand that preventative interventions, early diagnosis, and that treatment of dementia syndromes are available, and how these can impact significantly on the progression of the disease. 
Nurses are optimally placed to initiate and co-ordinate dementia education and services. A person living with dementia will transcend most services in the hospital and community requiring an informed workforce to deliver care. Nurses remain the predominant workforce across hospital and community settings. Therefore, it is essential for nurses to be culturally competent, which includes an understanding of how culture impacts on their own, as well as their colleagues, patients with dementia and family members' beliefs and values regarding dementia and dementia care.

Dementia services also need to be aligned to different cultural traditions, including that of filial piety, where respite services may be acceptable when permanent placement of a relative in a residential setting could place unprecedented stress, shame and anxiety on the family. The need to adapt to the culture of the host country as well as the culture of the workplace is an important aspect of migrant care workers acculturation.

A recurrent theme was the need for care staff to understand the host country's language, including medical terminology, slang and colloquial terms. Open access training and education on communication addressing these and other aspects such as accents, behavioural and facial communication need to be developed. Further research is required on the dynamic nature of acculturation and how this process impacts on person-centred dementia care provided by a culturally diverse workforce. This work needs to continue in residential care settings, but also expanded to understand the impact of these processes with acute care settings.

\section{Ethical approval}

No ethical approval was required for this research.

\section{Acknowledgements}

None to declare

\section{Author Contributions}

J.B. conceived and designed the study. J.B, M.S., C.C. and O.O. analysed, interpreted and wrote the article. J.B and C.C extracted, analysed and interpreted the data.

\section{REFERENCES}

Alzheimer's Disease International (2015) World Alzheimer Report 2015, London: The Global Impact of Dementia An analysis of prevalence, incidence, cost \& trends. Available at: https://www.alz.co.uk/research/WorldAlzheimerReport2015.pdf (accessed 23 September 2016). 
Antelius E, Kiwi M (2015) Frankly, none of us know what dementia is: dementia caregiving among Iranian immigrants living in Sweden. Care Management Journals 16(2), 79-94.

Arends-Tóth JV, van de Vijver FJR (2006) Issues in conceptualization and assessment of acculturation. In M. H. Bornstein \& L. R. Cote (Eds.) Acculturation and parent-child relationships: Measurement and development (pp. 33-62). Mahwah, NJ: Lawrence Erlbaum. Berry J W (2003) Conceptual approaches to acculturation. In K. M. Chun, P. B. Organista, \& G. Marín (Eds.) Acculturation: Advances in theory, measurement and applied research (pp. 17-37). Washington, DC: American Psychological Association. Available at: http://dx.doi.org/10.1037/10472-004 (assessed 23 September 2016).

Berry WJ (2011) Integration and Multiculturalism: Ways towards Social Solidarity in Papers on Social Representations, 20, 2.1-2.21.

Bettany-Saltikov J (2012) How to Do a Systematic Literature Review in Nursing. Ashford Colour Press Ltd.: Gosport, UK.

Brodaty H, Donkin M (2009) Family caregivers of people with dementia. Dialogues in Clinical Neuroscience 11 (2): 217-228.

Boughtwood D, Shanley C, Adams J, Santalucia Y, Kyriazopoulos H, Pond D, Rowland J (2011) Culturally and Linguistically Diverse (CALD) families dealing with dementia: An examination of the experiences and perceptions of multicultural community link workers. Journal of Cross Cultural Gerontology 26, 365-377.

Brooker D (2004) What is person centred care for people with dementia? Reviews in Clinical Gerontology 13, 215-222.

Celenk O, Van de Vijver F (2011) Assessment of Acculturation: Issues and Overview of Measures. Online Readings in Psychology and Culture 8(1). Available at: http://dx.doi.org/10.9707/ 2307-0919.1105 (accessed 23 September 2016).

Critical Appraisal Skills Programme (CASP) (2014). CASP Checklist. www.casp uk.net Oxford. CASP.

Cohen L (1998) No aging in India: Alzheimer's, the bad family, and other modern things. Berkeley, CA: University of California Press.

Cooke A, Smith D, Booth A (2012) Beyond PICO: The SPIDER tool for qualitative evidence synthesis. Qualitative Health Research 22, 1435-1443.

Cooper C, MUkadam N, Katona C, Lyketsos C, Blazer D, Ames D, Rabins P, Brodat, H, de Mendonca Lima C, Livingston G (2013) Systematic review of the effectiveness of 
Pharmacological interventions to improve the quality of life and well-being in people with dementia. The American Journal of Geriatric Psychiatry 21(2), 173-183.

Department of Health (2009) Living well with dementia: A national dementia Strategy. Available at:

https://www.gov.uk/government/uploads/system/uploads/attachment data/file/168221/dh 09 4052.pdf (accessed 23 September 2016).

Dilworth-Anderson P, Gibson B (2002) The cultural influence of values, norms, meaning and perceptions in understanding dementia in ethnic minorities. Alzheimer Disease and Associated Disorders 16 (Suppl 2), s56-s63.

Douglass C, Keddie A, Brooker D, Surr C (2010). Cross-cultural comparison of the perceptions and experiences of dementia care mapping "mappers" in the United States and the United Kingdom. Journal of Aging and Health 22(5), 567-588.

Egede-Nissen V, Sellevold G, Jakobsen R, Sørlie V (2016) Ethical and cultural striving: Lived experiences of minority nurses in dementia care. Nursing Ethics p.0969733015624489.

Emilsson UM (2011) The staff's view on dementia and the care in three cultures: A qualitative study in France, Portugal and Sweden. Dementia 11(1), 31-47.

Flaskerud J (2009) Dementia, ethnicity, and culture. Issues in Mental Health Nursing. 30(8), 522-523.

Gheno R, Cepparo J M, Rosca CE, Cotten A (2012). Musculoskeletal Disorders in the Elderly. Journal of Clinical Imaging Science 2:39. doi.org/10.4103/2156-7514.99151.

Gillespie RJ, Harrison L, Mullan J (2015) Medication management concerns of ethnic minority family caregivers of people living with dementia. Dementia 14(1), 47-62.

Goldman C (2009) Vietnamese Cultural Profile. An initiative of Old partners in culturally appropriate care. Available at: http://www.diversicare.com.au/wpcontent/uploads/2015/10/Vietnamese.pdf (accessed $6^{\text {th }}$ October 2016).

Greaves Z (2013) Are we responsible for our elderly relatives as we are for our children? Connecting Doctors. Available at: www.bma.org.uk (accessed $6^{\text {th }}$ October 2016).

Griffith JK (2009). The religious aspects of nursing care. Available at: http://web.uvic.ca/ nswb/ReligiousAspectsofNursingCareEEdition.pdf (accessed $6^{\text {th }}$ October 2016). 
Hannes K, Lockwood C (2011) Pragmatism as the philosophical foundation for the Joanna Briggs meta-aggregative approach to qualitative evidence synthesis. Journal of Advanced Nursing 67, 1632-1642.

Hanssen I (2012) The influence of cultural background in intercultural dementia care: exemplified by Sami patients. Scandinavian Journal of Caring Sciences 27, 231-237. Hanssen I, Kuven B (2016) Moments of joy and delight: the meaning of traditional food in dementia care. Journal of Clinical Nursing 25(5/6), 866-874.

Ho K, Chiang V (2015) A meta-ethnography of the acculturation and socialization experiences of migrant care workers'. Journal of Advanced Nursing 71(2), 237-254.

Kanwar S, Whomsley S (2011) Working with Pakistani service users and their families. A practitioner's guide. Available at: www.cpft.nhs.uk (accessed $6^{\text {th }}$ October 2016).

Kimzey M, Mastel-Smith B, Alfred D (2015) The impact of educational experiences on nursing students' knowledge and attitudes toward people with Alzheimer's disease: A mixed method study. Nurse Education Today 46, 57-63.

Kitwood T (1997) Dementia reconsidered: the person comes first. Open University Press: Buckingham.

Komaric N, Bedford S, van Driel ML (2012) Two sides of the coin: patient and provider perceptions of health care delivery to patients from culturally and linguistically diverse backgrounds. BMC Health Service Research 12:322 doi: 10.1186/1472-6963-12-322.

Leininger M. (1997) Overview of the theory of culture care with the ethnonursing research method. Journal of Transcultural Nursing 8(2), 32-52.

Livingston G, Kelly L, Lewis -Holmes E, Baio G, Morris S, Patel N, Omar R, Katona C, Cooper C (2014) Non-pharmacological interventions for agitation in dementia: A systematic review of randomised controlled trails. The British Journal of Psychiatry 205(6), 436-442.

Matsumoto D (1996) Culture and Psychology. Pacific Grove, CA: Brooks/Cole.

McCabe LF (2006) The cultural and political context of the lives of people with dementia in Kerala, India. Dementia 5(11), 7-156.

Moher D, Liberati A, Tetzlaff J, Altman DG and The PRISMA Group. Preferred reporting items for systematic reviews and meta-analyses: The PRISMA statement. PLoS Med. 2009: 6(6): e1000097. doi:10.1371/journal. pmed1000097. 
National Institute for Health and Clinical Excellence Guidelines (2006) CG42: Dementia: Supporting people with dementia and their carers. https://www.nice.org.uk/guidance/CG42 (last accessed 06/10/2016).

Nichols P, Horner B, Fyfe K (2015) Understanding and Improving communication processes in an increasingly multicultural aged care workforce. Journal of Aging Studies 32, 23-31.

O’Connor D, Phinney A, Smith A, Small J, Purves B, Perry J, Drance E, Donnelly M, Chaudhury $\mathrm{H}$, Beattie L (2007) Personhood in dementia care. Developing a research agenda for broadening the vision. Dementia 6(1), 121-142.

O'Neill F (2011) From language classroom to clinical context: the role of language and culture in communication for nurses using English as a second language. A thematic analysis. International Journal of Nursing Studies 48. 1120-1128.

Orsulic-Jeras S, Whitlatch CJ, Szabo SM (2016) The SHARE program for dementia: Implementation of an early-stage dyadic care planning intervention. Dementia doi: $10.1177 / 1471301216673455$.

Prince M, Knapp M, Guerchet M, McCrone P, Prina M, Comas-Herrera A, Wittenberg R, Adelaja B, Hu B, King D, Rehill A, Salimkumar D (2014) Dementia UK: Update. Alzheimer's Society.

Redfield R, Linton R, Herskovits MJ (1936) Memorandum for the study of acculturation. American Anthropologist 38, 149-152.

Reijnders J, van Heugten C, van Boxtel M (2013) Cognitive interventions in healthy older adults and people with mild cognitive impairment: A systematic review. Ageing Research Reviews 12(1), 263-275.

Scottish Intercollegiate Guidelines Network (2006) SIGN 86: Management of patients with dementia. A national clinical guideline. Edinburgh (Scotland): Scottish Intercollegiate Guidelines Network (SIGN): Feb. 53 publication: no 86.

Shanley C, Boughtwood D, Adams J, Santalucia Y, Kyriazopoulos H, Pond D, Rowland J (2012) A qualitative study into the use of formal services for dementia by carers from culturally and linguistically diverse (CALD) communities. BMC Health Service Research 12:354 DOI: 10.1186/1472-6963-12-354.

Spencer-Oatey H (2012) What is culture? A compilation of quotations. GlobalPAD Core Concepts. Available at: http://go.warwick.ac.uk/globalpadintercultural (accessed $6^{\text {th }}$ October 2016). 
UNESCO (2009) UNESCO World Report - Investing in Cultural Diversity and Intercultural Dialogue. United Nations Educational, Cultural and Scientific Organization: France.

Walsh K, Shutes I (2013) Care relationships, quality of care and migrant workers caring for older people. Ageing and Society 33(3), 393-420.

van Wezel N, Francke AL, Kayan-Acun E, Lym Deville W, van Grondelle NJ, Brom MM (2016) Family care for immigrants with dementia: The perspectives of female carers living in the Netherlands. Dementia 15(1), 69-84.

Wheeler RM, Foster JW, Hepburn KW (2013) The experiences of internationally educated nurses in the southeastern United States of America. International Nursing Review 60, 397404.

World Health Organisation (2006) Neurological Disorders: Public Health Challenges.

Available at:

http://www.who.int/mental health/neurology/neurological disorders report web.pdf (accessed 6th October 2016).

Wright RW, Brand RA, Dunn W, Spindler KP (2007) How to write a systematic review. Clinical Orthopaedics and Related Research 455: 23-29.

Xiao LD, De Bellis A, Habel L, Kyriazopoulos H (2013) The experiences of culturally and linguistically diverse family caregivers in utilising dementia services in Australia. BMC Health Science Research 13:427 doi 10.1186/1472-6963-13-427

Xiao LD, Habel L, De Bellis A (2015) Perceived challenges in dementia care by Vietnamese family caregivers and care workers in South Australia. Journal of Cross Cultural Gerontology 30, 333-352.

Yan E, Kwok T (2010) Abuse of older Chinese with dementia by family caregivers: an inquiry into the care of caregiver burden. International Journal of Geriatric Psychiatry 26(5): $527-$ 535.

Yong OW, Manthorpe J (2016) The experiences of Indian migrant care home staff working with people with dementia: a pilot study exploring cultural perspectives. Working with Older People 20(1), 3-13.

Yuan X, Wang Q (2011) A tentative study on differences and integration of Sino-Western filial piety culture. Asian Social Science 7(8), DOI: http://dx.doi.org/10.5539/ass.v7n8p97. 
Zhou Y, Windsor C, Theobald K, Coyer F (2011) The concept of difference and the experience of China-educated nurses working in Australia: a symbolic interactionist exploration. International Journal of Nursing Studies 48, 1420-1428. 
Figure 1: Process of literature search: PRISMA (Moher et al. 2009)

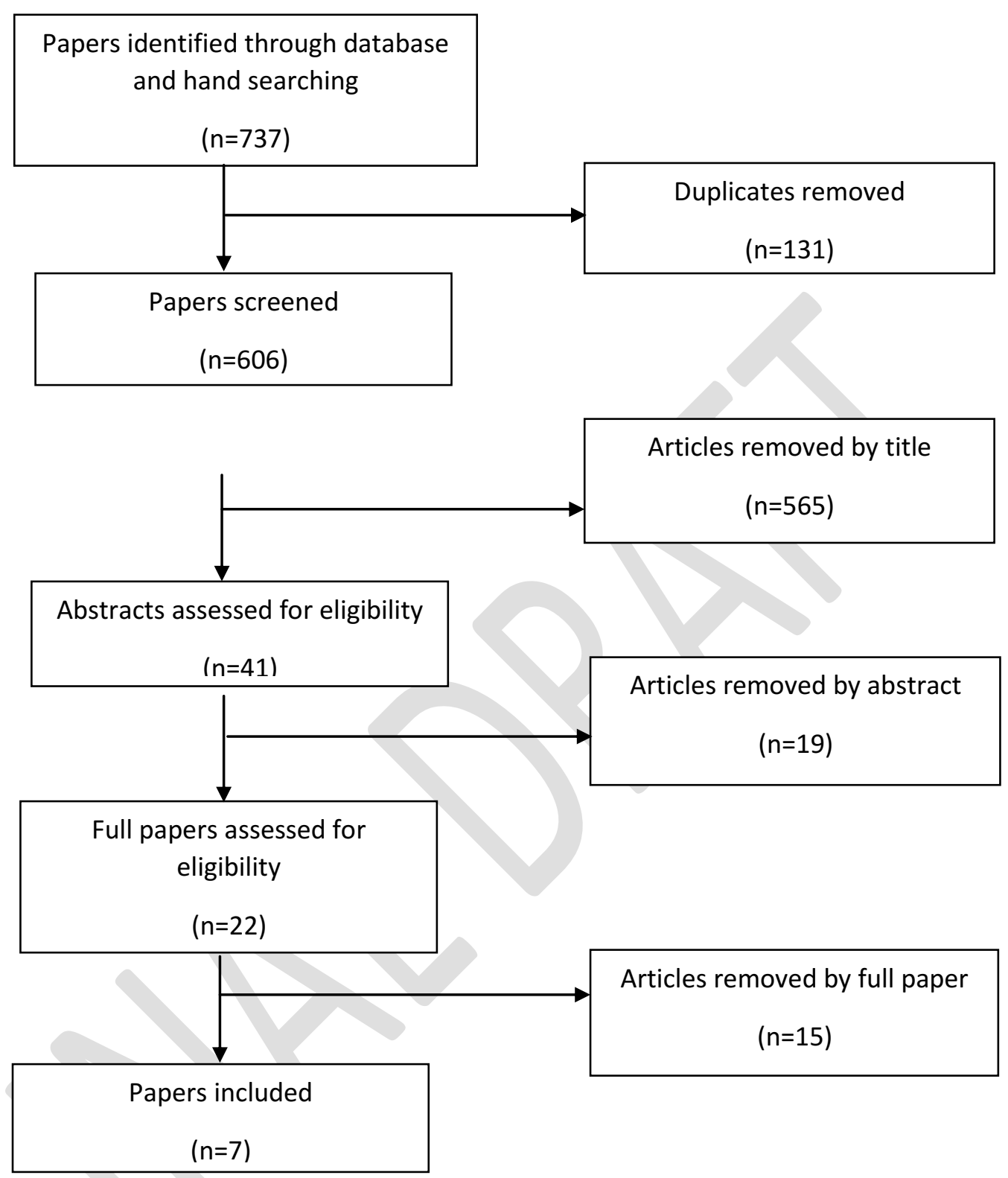


Table 1: Overview of included studies

\begin{tabular}{|c|c|c|c|c|c|c|}
\hline $\begin{array}{l}\text { Author, year, } \\
\text { country }\end{array}$ & Aim & Methods & Setting & Participants & Results & Discussion \\
\hline $\begin{array}{l}\text { Antelius \& } \\
\text { Kiwi } \\
2015 \\
\text { Sweden }\end{array}$ & $\begin{array}{l}\text { To explore } \\
\text { dementia } \\
\text { caregiving of } \\
\text { Iranian immigrants } \\
\text { providing ethno- } \\
\text { cultural dementia } \\
\text { care with a Middle } \\
\text { Eastern, Arab } \\
\text { and/or Persian } \\
\text { profile }\end{array}$ & $\begin{array}{l}\text { Qualitative } \\
\text { Semi-structured } \\
\text { interviews and } \\
\text { observations } \\
\text { Content and } \\
\text { ethnographic } \\
\text { analysis }\end{array}$ & $\begin{array}{l}\text { One residential } \\
\text { care facility } \\
\text { One home help } \\
\text { service }\end{array}$ & $\begin{array}{l}34 \text { ( } 29 \text { female, } 5 \text { male) } \\
\text { Participants role: } \\
\text { Assistant nurses }(n=27) \\
\text { Certified nurses }(n=3) \\
\text { Care managers }(n=2) \\
\text { Chief }(n=1) \\
\text { Activity leader }(n=1)\end{array}$ & $\begin{array}{l}\text { Four main findings: } \\
\text { 1) People from different } \\
\text { CaLD* backgrounds } \\
\text { have different } \\
\text { perceptions of } \\
\text { dementia } \\
\text { 2) Ascribed meaning of } \\
\text { dementia influences: } \\
\text { health behaviours, } \\
\text { health-seeking and } \\
\text { use of services } \\
\text { 3) The use of } \\
\text { ethnoculturally } \\
\text { profiled dementia } \\
\text { care facilities } \\
\text { 4) Culture is a relevant } \\
\text { aspect of peoples' } \\
\text { lives that is both } \\
\text { acquired and } \\
\text { ascribed to oneself } \\
\text { and to others }\end{array}$ & $\begin{array}{l}\text { The importance of } \\
\text { understanding the } \\
\text { culture of individuals } \\
\text { providing multicultural } \\
\text { dementia care and how } \\
\text { they ascribe meaning to } \\
\text { dementia, cultural } \\
\text { identities, and } \\
\text { behaviour of people } \\
\text { with dementia. }\end{array}$ \\
\hline $\begin{array}{l}\text { Boughtwood } \\
\text { et al. } \\
2011 \\
\text { Australia }\end{array}$ & $\begin{array}{l}\text { To explore multi- } \\
\text { cultural link } \\
\text { workers } \\
\text { experiences and } \\
\text { perceptions with } \\
\text { regard to the } \\
\text { cultural traditions }\end{array}$ & $\begin{array}{l}\text { Qualitative } \\
\text { Semi-structured } \\
\text { interviews } \\
\text { A modified version } \\
\text { of framework }\end{array}$ & $\begin{array}{l}4 \times \text { CALD } \\
\text { communities }\end{array}$ & $\begin{array}{l}24 \text { ( } 22 \text { female, } 2 \text { male) } \\
\text { Language background: } \\
\text { Arabic }(n=6) \\
\text { Chinese }(n=7) \\
\text { Italian }(n=4) \\
\text { Spanish }(n=7)\end{array}$ & $\begin{array}{l}\text { Three main themes: } \\
\text { 1) Cultural and familial } \\
\text { norms pertaining to } \\
\text { illness and older } \\
\text { people, including: } \\
\text { keeping dementia in } \\
\text { the family, judged by }\end{array}$ & $\begin{array}{l}\text { The cultural link workers } \\
\text { confirmed the differing } \\
\text { views and } \\
\text { interpretations of } \\
\text { dementia of CALD family } \\
\text { caregivers from that of } \\
\text { Anglo populations. }\end{array}$ \\
\hline
\end{tabular}




\begin{tabular}{|c|c|c|c|c|c|c|}
\hline & $\begin{array}{l}\text { informing CALD } \\
\text { family care-giving } \\
\text { in dementia }\end{array}$ & analysis & & $\begin{array}{l}\text { Participants roles: } \\
\text { Service coordinator } \\
(n=3) \\
\text { Direct care worker } \\
(n=10) \\
\text { Community } \\
\text { development }(n=4) \\
\text { Group worker }(n=7)\end{array}$ & $\begin{array}{l}\text { the community and } \\
\text { women as carers } \\
\text { 2) Understanding and } \\
\text { naming the term } \\
\text { 'carer' } \\
\text { 3) Patterns in family } \\
\text { caregiving }\end{array}$ & $\begin{array}{l}\text { One important aspect } \\
\text { was the lack of } \\
\text { understanding of the } \\
\text { term carer, or the } \\
\text { implications of being a } \\
\text { carer. }\end{array}$ \\
\hline $\begin{array}{l}\text { Egede-Nissen } \\
\text { et al. } \\
2016 \\
\text { Norway }\end{array}$ & $\begin{array}{l}\text { To explore caring } \\
\text { challenges } \\
\text { minority } \\
\text { healthcare } \\
\text { providers may } \\
\text { encounter in } \\
\text { relation to persons } \\
\text { with dementia }\end{array}$ & $\begin{array}{l}\text { Qualitative } \\
\text { narrative approach } \\
\text { Individual } \\
\text { interviews } \\
\text { Phenomenological- } \\
\text { hermeneutical } \\
\text { analysis }\end{array}$ & Nursing home & $\begin{array}{l}5 \text { (4 female, } 1 \text { male) } \\
\text { Brazilian }(n=1) \\
\text { Philippine }(n=1) \\
\text { Monte Negro }(n=2) \\
\text { Serbia ( } n=1) \\
\text { Participant roles: } \\
\text { Auxiliary nurse }(n=1) \\
\text { Nurse ( } n=3) \\
\text { Physiotherapist }(n=1)\end{array}$ & $\begin{array}{l}\text { One theme: Striving to } \\
\text { understand the quality of } \\
\text { care for persons with } \\
\text { dementia, with sub- } \\
\text { themes: sensitivity to } \\
\text { understand - the } \\
\text { patients' verbal and non- } \\
\text { verbal expressions, the } \\
\text { patient as an adult and } \\
\text { autonomous person, as a } \\
\text { patient in a nursing } \\
\text { home. }\end{array}$ & $\begin{array}{l}\text { The uncertainty around } \\
\text { reciprocal } \\
\text { communication and } \\
\text { interpretation of verbal } \\
\text { and nonverbal } \\
\text { expressions contributed } \\
\text { to uncertainty, mutual } \\
\text { stress and anxiety. }\end{array}$ \\
\hline $\begin{array}{l}\text { Emilsson } \\
2011 \\
\text { Sweden }\end{array}$ & $\begin{array}{l}\text { To explore views } \\
\text { on the illness of } \\
\text { dementia, on } \\
\text { older people with } \\
\text { dementia, and } \\
\text { cared delivered in } \\
\text { relation to the } \\
\text { cultural context } \\
\text { across three } \\
\text { cultures }\end{array}$ & $\begin{array}{l}\text { Qualitative } \\
\text { Individual } \\
\text { interviews and } \\
\text { observations } \\
\text { Content analysis }\end{array}$ & $\begin{array}{l}\text { In France and } \\
\text { Portugal } \\
\text { residential homes, } \\
\text { nursing homes and } \\
\text { hospital wards } \\
\text { In Sweden } 3 x \\
\text { municipal based } \\
\text { special housing } \\
\text { unit and } 3 x \text { county } \\
\text { council based }\end{array}$ & $\begin{array}{l}79 \text { including: } \\
\text { France }(n=23) \\
\text { Portugal }(n=22) \\
\text { Sweden }(n=34) \\
\text { Participant roles: } \\
\text { Physicians ( } n=7) \\
\text { Nurse }(n=20) \\
\text { Physiotherapist }(n=2) \\
\text { Occupational Therapist }\end{array}$ & $\begin{array}{l}\text { Four themes which } \\
\text { encompass different } \\
\text { views from each country: } \\
\text { 1) Old and III (France) } \\
\text { 2) Old in need of help } \\
\text { (Portugal) } \\
\text { 3) Old } \\
\text { patients/residents } \\
\text { (Sweden) }\end{array}$ & $\begin{array}{l}\text { Cultural context } \\
\text { impacted on the care } \\
\text { provided, however } \\
\text { professional affiliation } \\
\text { and collaborative } \\
\text { working supported } \\
\text { integrative care models } \\
\text { and care provided. }\end{array}$ \\
\hline
\end{tabular}




\begin{tabular}{|c|c|c|c|c|c|c|}
\hline & & & wards & $\begin{array}{l}(n=1) \\
\text { Social Worker }(n=1) \\
\text { Dietician }(n=12) \\
\text { Care worker }(n=1)\end{array}$ & & \\
\hline $\begin{array}{l}\text { Nichols et al. } \\
2015 \\
\text { Australia }\end{array}$ & $\begin{array}{l}\text { To explore how } \\
\text { culture shapes } \\
\text { relationships in } \\
\text { aged care and how } \\
\text { a multicultural } \\
\text { workforce is } \\
\text { supported }\end{array}$ & $\begin{array}{l}\text { Qualitative } \\
\text { Semi-structured } \\
\text { questionnaire and } \\
\text { a workshop }\end{array}$ & $\begin{array}{l}6 \text { residential care } \\
\text { facilties each with } \\
\text { a specific dementia } \\
\text { unit/ wing }\end{array}$ & $\begin{array}{l}\text { Management }(n=7) \\
\text { CaLD staff }(n=35) \\
\text { - } \quad \text { South-east Asia } \\
\quad(n=14) \\
\text { - } \quad \text { African }(n=12) \\
\text { - Pacific region }(n=7) \\
\text { - } \quad \text { European }(n=2) \\
\text { Non-CaLD staff }(n=11) \\
\text { Family member }(n=5)\end{array}$ & $\begin{array}{l}\text { CaLD staff experiences: } \\
\text { - } \quad \text { Staff reported more } \\
\text { negative interactions } \\
\text { than positive with } \\
\text { residents with } \\
\text { dementia due to } \\
\text { their cultural } \\
\text { differences } \\
\text { An element of } \\
\text { disharmony between } \\
\text { CaLD and non-CaLD } \\
\text { members of staff } \\
\text { The need to } \\
\text { understand the } \\
\text { culture, and } \\
\text { especially workplace } \\
\text { customs }\end{array}$ & $\begin{array}{l}\text { Developed a model to } \\
\text { support a multicultural } \\
\text { workforce in residential } \\
\text { care, which included } \\
\text { elements of: intrinsic } \\
\text { factors - beliefs and } \\
\text { values, moderating } \\
\text { factors - education and } \\
\text { experience, extrinsic } \\
\text { factors - policy, } \\
\text { guidelines and } \\
\text { workplace culture, and } \\
\text { the communication } \\
\text { process. }\end{array}$ \\
\hline $\begin{array}{l}\text { Yong \& } \\
\text { Manthorpe } \\
2016 \\
\text { England }\end{array}$ & $\begin{array}{l}\text { To explore Indian } \\
\text { migrant care } \\
\text { home staff's } \\
\text { experiences of } \\
\text { acculturation and } \\
\text { the impact on } \\
\text { their dementia } \\
\text { care practices }\end{array}$ & $\begin{array}{l}\text { Qualitative } \\
\text { Semi-structured } \\
\text { interviews } \\
\text { Interpretative } \\
\text { phenomenology } \\
\text { analysis }\end{array}$ & Care homes & $\begin{array}{l}12 \text { (11 female, } 1 \text { male) } \\
\text { Indian state of origin: } \\
\text { Kerala }(n=9) \\
\text { Punjab }(n=2) \\
\text { Gujarat }(n=1) \\
\text { Religion: } \\
\text { Christianity }(n=4) \\
\text { Hinduism }(n=5) \\
\text { Sikhism }(n=2)\end{array}$ & $\begin{array}{l}\text { Five main themes were } \\
\text { identified along the } \\
\text { timeline of workplace } \\
\text { acculturation: } \\
\text { 1) Received notion } \\
\text { 2) Sense of insecurity } \\
\text { 3) Identity evaluation } \\
\text { 4) Sense of competence } \\
\text { - Hope }\end{array}$ & $\begin{array}{l}\text { Employers and human } \\
\text { resources need to } \\
\text { support migrant } \\
\text { workers during } \\
\text { workplace acculturation } \\
\text { across an appropriate } \\
\text { timeline. }\end{array}$ \\
\hline
\end{tabular}




\begin{tabular}{|c|c|c|c|c|c|c|}
\hline & & & & $\begin{array}{l}\text { Roman Catholic }(n=1) \\
\text { Participant roles: } \\
\text { Qualified nurses }(n=3) \\
\text { Care workers }(n=9)\end{array}$ & & \\
\hline $\begin{array}{l}\text { Xiao et al. } \\
2015 \\
\text { Australia }\end{array}$ & $\begin{array}{l}\text { To explore the } \\
\text { perceived } \\
\text { challenges of both } \\
\text { Vietnamese family } \\
\text { caregivers and } \\
\text { care workers }\end{array}$ & $\begin{array}{l}\text { Qualitative } \\
\text { In-depth interviews } \\
\text { and a focus group } \\
\text { Gadamer's } \\
\text { philosophical } \\
\text { hermeneutics were } \\
\text { applied to } \\
\text { interpret the data }\end{array}$ & $\begin{array}{l}\text { Welfare } \\
\text { community } \\
\text { organisation } \\
\text { providing welfare } \\
\text { services: care } \\
\text { support groups, } \\
\text { day care, } \\
\text { community aged } \\
\text { care package }\end{array}$ & $\begin{array}{l}6 \text { ( } 4 \text { female, } 2 \text { male) } \\
\text { family caregivers } \\
7 \text { ( } 6 \text { female, } 1 \text { male) } \\
\text { care workers } \\
\text { All born in Vietnam }\end{array}$ & $\begin{array}{l}\text { Five main themes were: } \\
\text { 1) Need for culturally } \\
\text { and linguistically } \\
\text { appropriate } \\
\text { dementia education } \\
\text { programs } \\
\text { 2) Willingness and } \\
\text { unwillingness to seek } \\
\text { help } \\
\text { 3) Poor knowledge of } \\
\text { health care service } \\
\text { availability related to } \\
\text { dementia } \\
\text { 4) Effect of the } \\
\text { language barrier in } \\
\text { accessing care } \\
\text { services } \\
\text { 5) Main sources of } \\
\text { services utilized }\end{array}$ & $\begin{array}{l}\text { Vietnamese family } \\
\text { caregivers and care } \\
\text { workers expressed } \\
\text { different opinions } \\
\text { regarding stigma } \\
\text { associated to dementia. } \\
\text { The findings support an } \\
\text { in depth understanding } \\
\text { of Vietnamese family } \\
\text { caregivers and how } \\
\text { these may differ from } \\
\text { Vietnamese care } \\
\text { workers. }\end{array}$ \\
\hline
\end{tabular}

${ }^{*}$ CaLD = culturally and linguistically diverse 